\title{
The combined effects of thinning and prescribed fire on carbon and nutrient budgets in a Jeffrey pine forest
}

\author{
Dale.W. Johnson ${ }^{1 *}$, James D. MURPHY ${ }^{1}$, Roger F. WALKER ${ }^{1}$, Watkins W. MiLleR ${ }^{1}$, D.W. GLASs ${ }^{1}$, \\ Donald E. ToDD Jr. ${ }^{2}$ \\ ${ }^{1}$ Natural Resources and Environmental Science, University of Nevada, Reno, Nevada, 89557, USA \\ ${ }^{2}$ Environmental Sciences Division, Oak Ridge National Laboratory, Oak Ridge, Tennessee, USA
}

(Received 2 January 2008; accepted 30 April 2008)

\begin{abstract}
-
- Both burning and harvesting cause carbon and nutrient removals from forest ecosystems, but few studies have addressed the combination of these effects. For a Pinus jeffreyii forest in the Sierra Nevada Mountains of California, we posed the question: what are the relative impacts of thinning and subsequent burning on carbon and nutrient removals?

- The thinning methods included whole-tree thinning (WT, where all aboveground biomass was removed) cut to length (CTL, where branches and foliage were left on site in a slash mat on top of skid trails) and no harvest (CONT). Total C and nutrient exports with thinning and burning were greater in the WT and CTL than in the CONT treatments. Total C and N removals were approximately equal for the WT and CTL treatments, although harvesting dominated exports in the WT treatment and burning dominated exports in the CTL treatment. Total removals of P, K, Ca, Mg and S were greatest in the WT treatments, where harvesting dominated removals.

- Comparisons of nutrient removals with ecosystem capital and calculations of potential replenishment by atmospheric deposition suggested that $\mathrm{N}$ is the nutrient likely to be most depleted by harvesting and burning treatments.
\end{abstract}

harvesting / prescribed fire / nutrients / Pinus jeffreyii / Sierra Nevada Mountains

Résumé - Effets combinés de l'éclaircie et des feux prescrits sur les budgets de carbone et de nutriments.

- L'un et l'autre, le brûlage et les récoltes, causent un enlèvement important de carbone et de nutriments dans les écosystèmes forestiers, mais peu de travaux se sont attelés à l'étude de la combinaison de ces effets. Pour une forêt de Pinus jeffreyii nous posons la question suivante : quels sont les impacts relatifs d'une éclaircie et d'un brûlage ultérieur sur l'enlèvement du carbone et des nutriments, dans les Montagnes de la Sierra Nevada en Californie ? - Les méthodes d'éclaircie comprennent : éclaircie totale des arbres (WT, toute la biomasse au-dessus du sol est enlevée), coupe à la dimension désirée (CTL, branches et feuillage ont été laissés sur site en andains) et pas de récolte (CONT). L'exportation totale de carbone et de nutriments avec éclaircie et brûlage dans les traitements WT et CTL a été plus importante que dans le traitement CONT. Les sommes totales de carbone et d'azote enlevées ont été approximativement les mêmes pour les traitements WT et CTL, bien que la récolte est été prédominante dans les exportations pour le traitement WT et que le brûlage soit prédominant dans les exportations pour le traitement CTL. Le total des enlèvements de P, K, Ca, Mg et S dans le traitement WT a été le plus grand dans les traitements WT où la récolte était plus importante que l'enlèvement.

- La comparaison des nutriments enlevés par rapport au capital de l'écosystème et le calculs de réapprovisionnement par des apports atmosphériques suggère que l'azote $(\mathrm{N})$ est le nutriment probablement le plus épuisé par les traitements de récolte et de brûlage.

récolte / feux prescrits / nutriments / Pinus jeffreyii / montagnes de la Sierra Nevada

\section{INTRODUCTION}

Decades of ill-advised fire suppression have resulted in an unprecedented buildup of fuels in forests of the southwestern US that are contributing, along with climate warming, to an increased incidence of catastrophic wildfire (Westerling et al., 2006). Efforts to mitigate the problem are past due, but are now underway and include mechanical removal of understory and thinning to improve forest health, prescribed fire on a regular basis, or both. Both harvesting and fire cause nutrient removals. Many studies of harvesting effects have shown that bole-only harvesting of mature trees results in minimal

* Corresponding author: dwj@ cabnr.unr.edu removals of nutrients because of the very low nutrient concentrations in woody tissues (Boyle et al., 1973; Johnson and Todd, 1998; Johnson et al., 1982, 1988; Mann et al., 1988). Whole-tree harvesting, on the other hand, causes disproportionately higher removals of nutrients because of the high nutrient concentrations in foliage and branch tissues (Boyle et al., 1973; Johnson et al., 1982; Mann et al., 1988; Weetman and Weber, 1972). Many studies suggest that fertilization will be required to maintain nutrient status on sites subjected to whole tree harvesting. Removal of understory and juvenile trees also results in disproportionately greater nutrient removals than cut to length harvest for the same reasons.

Prescribed fire can cause significant losses of volatile nutrients as well. Carbon, N, and S are readily volatilized at low 
burn temperatures and therefore are lost as gases during the combustion of forest floor and understory biomass (Caldwell et al., 2002; Hosking, 1938; Knight, 1966; Raison et al., 1985; Tiedemann, 1987). Several studies have shown that burning results in near total loss of the $\mathrm{N}$ contained in burned organic matter (see reviews by Certini 2005; Neary et al., 1999; Raison et al., 1985). Sulfur is lost at higher temperatures and is often left behind as sulfate in low-intensity prescribed fires (e.g., Blank and Zamudio, 1998). Other elements, such as P, K, Ca, and $\mathrm{Mg}$ require much greater burn temperatures to volatilize and therefore remain on site as ash unless they are removed as a result of off-site particulate transport (i.e. convection during fire or post-fire removal of ash by wind or water; Raison et al., 1985; Malmer, 1996).

The objectives of this study were to quantify the effects of mechanical thinning and subsequent prescribed fire on nutrient budgets in a Sierra Nevada Ecosystem. The thinning treatments included whole-tree (WT, where all aboveground biomass was removed along skid trails) and cut to length (CTL, where branches and foliage were left on site in a slash mat on top of skid trails) in addition to a no-harvest control treatment (CONT). Previous studies at this site have addressed forest floor and soil concentration changes due to burning (Murphy et al., 2006), fuels (Walker et al., 2006), tree water relations (Fecko et al., 2008a), and stand structure and mortality (Fecko et al., 2008b). In this paper, we synthesize much of this data, calculate masses and nutrient contents of soils, forest floor and vegetation, and assess the effects of thinning and burning on the exports of carbon and nutrients. Based upon a review of the literature, we posed the following hypotheses:

H1: Total carbon and nutrient removals by harvesting plus burning will be greater in the harvest treatments (CTL and WT) than in the unharvested (CONT) treatment.

$\mathrm{H} 2$ : Harvest type (CTL vs. WT) will have little effect on the combined effects of harvesting and burning on $\mathrm{C}$ and $\mathrm{N}$ losses despite the large differences in removal by harvesting because $\mathrm{C}$ and $\mathrm{N}$ in residues left in CTL treatments will be substantially lost during burning.

$\mathrm{H} 3$ : Harvesting will be the dominant mechanism for $\mathrm{C}$ and $\mathrm{N}$ removal in the WT treatment whereas burning will dominate $\mathrm{C}$ and $\mathrm{N}$ removal in the CTL treatment.

$\mathrm{H} 4$ : Harvesting treatments will dominate the combined effects of harvesting and burning on losses of $\mathrm{P}, \mathrm{K}, \mathrm{Ca}, \mathrm{Mg}$, and $\mathrm{S}$, and removals will be greatest in WT.

\section{MATERIALS AND METHODS}

\subsection{Site}

The site is located approximately $32 \mathrm{~km}$ north of Truckee, California, in the Tahoe National Forest in the Sierra Nevada. The site is at an elevation of $1767 \mathrm{~m}$ and receives an average of $94 \mathrm{~cm}$ annual precipitation, most of which occurs as snow. Overstory vegetation is dominated by 95-107 year-old Jeffery pine (Pinus jeffreyi [Grev. and Balf.]) with a few scattered white fir (Abies concolor [Gord. and Glend.] Lindl.). Prior to thinning, the stand averaged 365 stems ha ${ }^{-1}$ and a basal area of $30.2 \mathrm{~m}^{2} \mathrm{ha}^{-1}$ (Fecko et al., in press). Understory vegetation consists of sagebrush (Artemesia tridentata [Nutt.]), bitterbrush (Purshia tridentata [DC.]), mule's-ears (Wyethia mollis [A. Gray]), green leaf manzanita (Arctostaphylos patula [Green]), and squawcarpet (Ceanothus prostratus [Benth.]). Soils are the Kyburz series, fine-loamy, mixed, frigid Ultic Haploxeralfs derived from andesite. Some basic soil physical and chemical properties are given in Table I.

\subsection{Experimental design}

The harvest treatments took place in the fall of 2000 (prior to the initiation of this study) and included unharvested control (CONT), cut-to-length thinning (CTL), and whole-tree thinning (WT). Each harvest treatment occurred in approximately a 5 ha block. In the CTL thinning, branches and foliage were left on site in slash mats as a surface for the skidders to remove tree boles. In the WT treatment, all above-stump material was removed by skidders on the skid trails. The slash mat/skid trail areas constituted $26 \pm 2 \%$ (average and standard error) of the area in the harvested plots, and approximately the same amount of tree biomass (40\%) was harvested in each case; thus, the primary difference in the harvest treatments was the presence or absence of slash in the slash mats/skid trails.

In the summer of 2001, ten replicate circular plots 0.04 ha in size were established in each harvest treatment and the unharvested control, five of which were subjected to a controlled underburn in May 2002. Ignition commenced at 1800 hours at an air temperature of $16{ }^{\circ} \mathrm{C}$, relative humidity of $48 \%$ and wind speed of $5.5 \mathrm{~km} \mathrm{~h}^{-1}$. Fuel moisture averaged $8 \%$ for fine fuels (1- and 10-h fuels, $<2.54 \mathrm{~cm}$ diameter) and $14 \%$ for coarser fuels (100- and 1000-h fuels, $>2.54 \mathrm{~cm}$ ).

\subsection{Forest floor and soil sampling}

For our study, we sampled only four of the five replicate plots within each treatment. Before the fire, $\mathrm{O}$ horizons were destructively sampled at six randomly-located points outside of the slash mat/skid trail areas and four randomly-located points within the nonslash mat/skid trails of the harvested treatments and in six randomlylocated points within the unharvested control. O horizons (forest floor) were destructively sampled by horizon within a $0.07 \mathrm{~m}^{2}$ ring at each sampling point. After the $\mathrm{O}$ horizons were removed, soils at each point were sampled by depth $(0-20,20-40$, and $40-60 \mathrm{~cm})$, corresponding to the $\mathrm{A}, \mathrm{B} 1 \mathrm{t}$, and $\mathrm{B} 2 \mathrm{t}$ horizons, respectively, using a bucket auger. Litter and soils were bulked by plot, so that there were four replicate bulked samples per treatment for each stratum (slash mat, skid trail, non-trail) and horizon.

Larger fuel was inventoried by time lag category (Pyne, 1984). The 100-h and 1000-h fuels were inventoried using circular plots with areas of $54 \mathrm{~m}^{2}$ and $4 \mathrm{~m}^{2}$, respectively, from each 0.04-ha plot center. For the 1000-h fuels, log length and diameter at the mid point were used to calculate a volume estimate according to the Huber formula (Avery and Burkhart, 2002). Volumes were then converted to a dry weight from measured dimension of 10 oven dried log sections.

Post-burn O horizon and ash samples were collected two weeks after the fire so as to avoid collecting fresh input of detritus from aboveground vegetation. Post-fire $\mathrm{O}$ horizons were collected in the same manner as pre-burn samples except that the remaining ash was collected separately using a small hand held vacuum. Because of time and logistical constraints, post-burn $\mathrm{O}$ horizon samples were 
Table I. Some basic physical and chemical properties of the soils before burning. (Adapted from Murphy et al., 2006).

\begin{tabular}{|c|c|c|c|c|c|c|}
\hline & \multirow{2}{*}{$\begin{array}{l}\text { Bulk density } \\
\qquad\left(\mathrm{g} \mathrm{cm}^{-3}\right)\end{array}$} & \multirow[t]{2}{*}{$\%>2 \mathrm{~mm}$} & \multirow[t]{2}{*}{$\mathrm{pH}_{\mathrm{CaCl} 2}$} & Carbon & Nitrogen & \multirow[t]{2}{*}{ C:N Ratio } \\
\hline & & & & \multicolumn{2}{|c|}{$\left(\mathrm{mg} \mathrm{kg}^{-1}\right)$} & \\
\hline \multicolumn{7}{|l|}{ Control } \\
\hline A $(0-20 \mathrm{~cm})$ & $0.85 \pm 0.07$ & $38 \pm 10$ & $5.4 \pm 0.05$ & $32.0 \pm 8.9$ & $1.72 \pm 0.29$ & $18.40 \pm 2.06$ \\
\hline B1t $(20-40 \mathrm{~cm})$ & $0.81 \pm 0.06$ & $32 \pm 4$ & $5.4 \pm 0.21$ & $21.6 \pm 5.7$ & $1.33 \pm 0.14$ & $16.04 \pm 2.41$ \\
\hline B2t $(40-60 \mathrm{~cm})$ & $0.80 \pm 0.06$ & $49 \pm 9$ & $5.5 \pm 0.20$ & $17.5 \pm 2.8$ & $1.18 \pm 0.08$ & $14.75 \pm 1.52$ \\
\hline \multicolumn{7}{|c|}{ Cut-to-length thinning } \\
\hline A $(0-20 \mathrm{~cm})$ & $0.73 \pm 0.06$ & $44 \pm 6$ & $5.1 \pm 0.12$ & $35.8 \pm 9.7$ & $1.75 \pm 0.30$ & $20.14 \pm 2.17$ \\
\hline B1t $(20-40 \mathrm{~cm})$ & $0.82 \pm 0.03$ & $47 \pm 18$ & $5.3 \pm 0.08$ & $24.9 \pm 7.4$ & $1.38 \pm 0.22$ & $17.72 \pm 3.02$ \\
\hline B2t $(40-60 \mathrm{~cm})$ & $0.87 \pm 0.08$ & $54 \pm 16$ & $5.4 \pm 0.15$ & $22.2 \pm 5.0$ & $1.32 \pm 0.22$ & $16.71 \pm 1.21$ \\
\hline \multicolumn{7}{|c|}{ Whole tree thinning } \\
\hline A $(0-20 \mathrm{~cm})$ & $0.80 \pm 0.05$ & $43 \pm 10$ & $5.1 \pm 0.07$ & $44.0 \pm 12.7$ & $1.89 \pm 0.42$ & $23.02 \pm 2.11$ \\
\hline B1t $(20-40 \mathrm{~cm})$ & $0.58 \pm 0.19$ & $44 \pm 12$ & $5.4 \pm 0.15$ & $25.5 \pm 2.9$ & $1.35 \pm 0.13$ & $18.88 \pm 1.24$ \\
\hline \multirow[t]{3}{*}{ B2t $(40-60 \mathrm{~cm})$} & $0.62 \pm 0.18$ & $37 \pm 12$ & $5.4 \pm 0.19$ & $18.9 \pm 7.2$ & $1.09 \pm 0.04$ & $17.25 \pm 6.17$ \\
\hline & Bicarbonate-P & Bray-P & Exch. $\mathrm{K}^{+}$ & Exch. $\mathrm{Ca}^{2+}$ & Exch. $\mathrm{Mg}^{2+}$ & \multirow{2}{*}{$\begin{array}{c}\text { Extr. } \mathrm{SO}_{4}{ }^{2-} \\
\left(\mu \mathrm{mol} \mathrm{kg}{ }^{-1}\right)\end{array}$} \\
\hline & \multicolumn{2}{|c|}{$\left(\mu \mathrm{mol} \mathrm{kg}{ }^{-1}\right)$} & \multicolumn{3}{|c|}{$\left(\mathrm{cmol}_{\mathrm{c}} \mathrm{kg}^{-1}\right)$} & \\
\hline $\bar{A}(0-20 \mathrm{~cm})$ & $1.11 \pm 0.27$ & $1.06 \pm 0.30$ & $0.93 \pm 0.11$ & $9.29 \pm 0.52$ & $2.34 \pm 0.31$ & $0.10 \pm 0.03$ \\
\hline B1t $(20-40 \mathrm{~cm})$ & $0.72 \pm 0.27$ & $0.57 \pm 0.16$ & $0.90 \pm 0.22$ & $9.81 \pm 1.41$ & $2.71 \pm 0.78$ & $0.07 \pm 0.02$ \\
\hline B2t $(40-60 \mathrm{~cm})$ & $0.50 \pm 0.08$ & $0.42 \pm 0.09$ & $0.80 \pm 0.20$ & $10.34 \pm 2.20$ & $3.15 \pm 1.14$ & $0.05 \pm 0.02$ \\
\hline \multicolumn{7}{|c|}{ Cut-to-length thinning } \\
\hline A $(0-20 \mathrm{~cm})$ & $0.87 \pm 0.18$ & $0.99 \pm 0.19$ & $0.91 \pm 0.10$ & $5.97 \pm 2.45$ & $1.38 \pm 0.86$ & $0.04 \pm 0.03$ \\
\hline B1t $(20-40 \mathrm{~cm})$ & $0.51 \pm 0.12$ & $0.79 \pm 0.27$ & $0.88 \pm 0.25$ & $6.48 \pm 1.74$ & $1.72 \pm 0.97$ & $0.06 \pm 0.04$ \\
\hline B2t $(40-60 \mathrm{~cm})$ & $0.45 \pm 0.18$ & $0.53 \pm 0.16$ & $0.97 \pm 0.44$ & $6.90 \pm 1.65$ & $1.93 \pm 0.96$ & $0.04 \pm 0.02$ \\
\hline \multicolumn{7}{|c|}{ Whole tree thinning } \\
\hline A $(0-20 \mathrm{~cm})$ & $0.62 \pm 0.25$ & $0.71 \pm 0.25$ & $0.94 \pm 0.30$ & $7.55 \pm 1.49$ & $2.30 \pm 1.59$ & $0.05 \pm 0.02$ \\
\hline B1t $(20-40 \mathrm{~cm})$ & $0.50 \pm 0.15$ & $0.52 \pm 0.18$ & $1.09 \pm 0.04$ & $7.73 \pm 1.21$ & $2.42 \pm 0.74$ & $0.05 \pm 0.01$ \\
\hline B2t $(40-60 \mathrm{~cm})$ & $0.40 \pm 0.36$ & $0.44 \pm 0.22$ & $0.90 \pm 0.17$ & $8.04 \pm 1.41$ & $2.91 \pm 0.90$ & $0.03 \pm 0.03$ \\
\hline
\end{tabular}

not taken from the unburned plots. Given the size of the standing organic pools in the $\mathrm{O}$ horizons prior to burning (approximately $20-40 \mathrm{Mg} \mathrm{ha}^{-1}$ ) and litterfall rates in these forest systems (1 to 1.5 $\mathrm{Mg} \mathrm{ha}^{-1} \mathrm{y}^{-1}$; Susfalk, 2000), we estimated that $\mathrm{O}$ horizon mass and nutrient contents in the absence of burning would change by less than $5 \%$ over the period of a year. On the other hand, $O$ horizon mass in the burned plots was reduced by 39 to $61 \%$ within two weeks (Murphy et al., 2006), values well beyond what could be attributed to normal changes in $\mathrm{O}$ horizon mass over that period of time.

Post-burn soil samples from both burned and control plots were taken one year after the fire (in June 2003) in order to allow ash to incorporate into the soil profile with winter rain and snow. O horizons were removed from sampling points and soils were sampled in the same manner as before the fire and bulked by treatment and horizon as before.

\subsection{Forest floor and soil sample processing}

O horizon samples were floated in water to separate large rocks from organic components. Post-burn $\mathrm{O}$ horizon samples were not floated due to the potential dissolving of residual ash and organic material that did not undergo complete combustion; therefore, large pebbles and rocks were picked out by hand. A $0.84 \mathrm{~mm}$ standard testing sieve was used to separate the mineral and organic fraction from post-burn $\mathrm{O}$ horizon samples. After this initial treatment, $\mathrm{O}$ horizon samples were dried at $105{ }^{\circ} \mathrm{C}$ and then subsamples were ground and analyzed for total $\mathrm{P}, \mathrm{K}, \mathrm{Ca}, \mathrm{Mg}$, and $\mathrm{S}$ at A\&L Agricultural Laboratories, Modesto, $\mathrm{CA}$. Phosphorus, $\mathrm{K}, \mathrm{Ca}, \mathrm{Mg}$, and $\mathrm{S}$ in vegetation and litter were analyzed using a Jarrell Ash ion coupled plasma spectrophotometer (ICP; Thermo Jarrell Ash Corp., Franklin, MA) after microwave digestion (Method 985.01, Association of Official Analytical Chemists) in a nitric acid hydrogen/peroxide mixture. Total $\mathrm{C}$ and $\mathrm{N}$ were analyzed using a dry combustion $\mathrm{C}$ and $\mathrm{N}$ analyzer (LECO, St. Joseph, MI) at the Oklahoma State University Soil, Water, and Forage Analytical Laboratory (Stillwater, OK).

All soil samples were oven dried at $55{ }^{\circ} \mathrm{C}$ (lower temperatures now recommended in order to avoid $\mathrm{NH}_{4}^{+}$volatilization) until weight losses ceased and passed through a $2 \mathrm{~mm}$ sieve. Samples were analyzed at A\&L Western Agricultural Laboratories, Modesto, California, USA for Bray-extractable $\mathrm{P}(2 \mathrm{~g}$ soil in $0.5 \mathrm{M} \mathrm{HCl}$ plus $\left.1 \mathrm{M} \mathrm{NH}_{4} \mathrm{~F}\right)$, and bicarbonate-extractable $\mathrm{P}(2 \mathrm{~g}$ soil in $50 \mathrm{~mL} 0.05 \underline{\mathrm{M}}$ $\mathrm{NaHCO}_{3}^{-}$) using a Jarrell Ash ion coupled plasma spectrophotometer (ICP; Thermo Jarrell Ash Corp., Franklin, MA). Soils were also analyzed for exchangeable $\mathrm{Ca}^{2+}, \mathrm{K}^{+}$, and $\mathrm{Mg}^{2+}(10 \mathrm{~g}$ soil in $50 \mathrm{~mL}$ $1 \mathrm{~N}$ ammonium acetate followed by ICP analyses) and for total $\mathrm{C}$ and total N (LECO Analyzer at the Soil, Water, and Forage Analysis Laboratory, Oklahoma State University, Stillwater, OK). Sulfate was analyzed by extracting $2.5 \mathrm{~g}$ of soil with $50 \mathrm{~mL}$ of deionized 
water followed by $\mathrm{SO}_{4}^{2-}$ analysis using high performance ion exchange chromatography (Dionex Corp, Sunnyvale, CA).

Some basic soil chemical properties for the sites before burning are given in Table I. As noted by Murphy et al (2006), there were pretreatment differences in soil chemical properties; the analyses of the effects of treatment took these into account whereby only significant treatment $\times$ time interaction terms in the analysis (before and after burning) were considered to indicated treatment effects.

\subsection{Soil mass and nutrient calculations}

Prior to the fire, quantitative soil pits were dug in the centers of all sampled plots using a modification of the method described by Hamburg (1984). In our method, the volume of the hole was calculated from the mass and density of the soil, stones, and woody material removed from the pits. In each quantitative pit a bulk density sample (core method) was taken at the top of each soil horizon following which, all soil, rock and roots were removed and field sieved $(1 \mathrm{~cm})$. The total amount of material in each size fraction from the field sieving ( $>1 \mathrm{~cm}$ and $<1 \mathrm{~cm}$ ) was weighed in the field. Subsamples were then taken of the $<1 \mathrm{~cm}$ fraction, stored in water-tight containers until reaching the laboratory, weighed, dried at $105^{\circ} \mathrm{C}$, and weighed again for moisture content corrections. The $>1 \mathrm{~cm}$ fraction consisted primarily of pebbles and rocks of various sizes and were subsampled for density determinations in the laboratory by weighing and measuring water displacement for volume. Woody debris that did not pass through the sieve was field weighed and subsampled for determinations of moisture content. The volume of soil in the pit was calculated from the weight of the $<1 \mathrm{~cm}$ fraction (corrected for moisture content) and the bulk density sample for each horizon, assuming that they represented the same size fraction. The volume of rocks in the pit was calculated from the field weights and density determinations. Finally, subsamples of the $<1 \mathrm{~cm}$ fraction were passed through a standard $2 \mathrm{~mm}$ sieve in the laboratory, and the weights of each fraction were then used with the above data to calculate a final value for fine earth $(<2 \mathrm{~mm})$ and coarse fragment $(>2 \mathrm{~mm})$ content. The fine earth $(<2 \mathrm{~mm})$ weight $\left(\mathrm{kg} \mathrm{ha}^{-1}\right)$ was then calculated by horizon and multiplied by nutrient concentrations to obtain nutrient mass.

\subsection{Forest floor mass and nutrient calculations}

In order to calculate the total area-weighted average forest floor $\mathrm{C}$ and nutrient content $\left(\mathrm{kg} \mathrm{ha}^{-1}\right)$ in the harvested treatments, forest floor nutrient content estimates from the litter ring values taken from within and outside the slash mat/skid trail areas were weighted by the respective areas of these two strata and added to the values for the 100 and 1000-h fuels. Total forest floor nutrient content estimates for the unharvested treatments were calculated by simple addition of the litter ring and large woody fractions.

\subsection{Vegetation biomass and nutrient calculations}

Tree biomass was estimated from measurements of diameter at breast height $(\mathrm{dbh}$, or $137 \mathrm{~cm})$ within each plot and applying the regression equations provided by Gholz et al. (1979) which were checked for accuracy for local trees (Johnson et al., 2005). Preharvest tree biomass was estimated from stump diameters which were in turn regressed against dbh from existing live trees and, dbh values where then used to calculate biomass of trees removed in the harvest (Walker et al., 2006). Within each plot, $54 \mathrm{~m}^{2}$ subplots were used for mapping of shrub and herbaceous understory species, permitting expression of the prevalence of individual species on a percent ground cover basis. In order to also express their prevalence on a dry weight basis, five samples of known ground cover area were collected from random locations for each species, dried and weighed. For shrub species, each sample consisted of all tissues occupying a ground area of $0.093 \mathrm{~m}^{2}$, while $0.01 \mathrm{~m}^{2}$ was used for herbaceous species.

Tree nutrient contents were calculated from concentrations measured on foliage, branch, and boles of samples from live trees taken before the burn. Samples were ground in a Wiley Mini-Mill (Thomas Scientific, Swedesboro, NJ) and analyzed using a Jarrell Ash ion coupled plasma spectrophotometer (Thermo Jarrell Ash Corp., Franklin, MA) after microwave digestion via a nitric acid hydrogen peroxide mixture at A\&L Western Agricultural Laboratories (Modesto, CA). Total $\mathrm{C}$ and $\mathrm{N}$ were analyzed using a dry combustion $\mathrm{C}$ and $\mathrm{N}$ analyzer (LECO, St. Joseph, MI) at the Oklahoma State laboratory.

\subsection{Statistical analyses}

Statistical analysis on the effects of harvest and burn treatments on the contents of $\mathrm{C}, \mathrm{N}, \mathrm{P}, \mathrm{K}, \mathrm{Ca}, \mathrm{Mg}$ and $\mathrm{S}$ in various ecosystem components and on the losses of these nutrients with harvesting and burning were performed using SAS ${ }^{\circledR}$ PROC MIXED software (SAS Institute Inc., Cary, NC) using four replicate plots (random effects) for each treatment combination (fixed effects). Post-hoc pairwise comparisons were conducted using least significant differences (Carmer and Swanson, 1973). Statistical significance was assigned to probability levels of $P \leq 0.05$.

\section{RESULTS}

Ecosystem C, N, P (including both Bray- and bicarbonateextractable $\mathrm{P}$ in soils), $\mathrm{K}, \mathrm{Ca}, \mathrm{Mg}$, and $\mathrm{S}$ contents after harvest but before burning are given in Table II. The sites were fairly similar in terms of tree $\mathrm{C}$ and nutrient contents, varying by 4 to $8 \%$. Trees accounted for 23 to $28 \%$ of total ecosystem C, 4 to $5 \%$ of total ecosystem N, 25 to $44 \%$ of ecosystem $\mathrm{P}$ (counting only extractable $\mathrm{P}$ in the soil), 13 to $16 \%$ of ecosystem $\mathrm{K}$ (counting only exchangeable $\mathrm{K}^{+}$in soil), 4 to $6 \%$ of ecosystem $\mathrm{Ca}^{2+}$ (counting only exchangeable $\mathrm{Ca}^{2+}$ in soil), 7 to $12 \%$ of ecosystem $\mathrm{Mg}$ (counting only exchangeable $\mathrm{Mg}^{2+}$ in soil), and 31 to $48 \%$ of ecosystem S (counting only extractable $\mathrm{SO}_{4}^{2-}$ in soil). There were no statistically significant differences in tree $\mathrm{C}$ or nutrient content among the harvest treatments. Understory (shrubs, seedlings, saplings) accounted for less than $1 \%$ of ecosystem $\mathrm{C}$ and nutrient content in all cases and again there were no statistically significant differences among harvest treatments. Carbon and nutrient contents of the forest floor (including large woody debris) were two to three times greater in the cut-to-length (CTL) plots than in the control (CONT) or whole-tree harvest (WT) plots because of the logging debris left in the former treatment. The soil accounted for 52 to $59 \%$ of total ecosystem C and 86 to $89 \%$ 
Table II. Ecosystem carbon and nutrient contents after harvest and before burning.

\begin{tabular}{|c|c|c|c|}
\hline & Unharvested & Cut-to-length thinning & Whole-tree thinning \\
\hline \multicolumn{4}{|l|}{$\overline{\text { Carbon }\left(\mathrm{Mg} \mathrm{ha}^{-1}\right)}$} \\
\hline Foliage & $2.4 \pm 0.4$ & $2.6 \pm 0.4$ & $2.6 \pm 0.3$ \\
\hline Branch & $7.7 \pm 1.7$ & $7.3 \pm 1.1$ & $7.9 \pm 1.1$ \\
\hline Bole & $26.3 \pm 5.6$ & $27.7 \pm 4.9$ & $27.0 \pm 3.8$ \\
\hline Total tree & $36.4 \pm 7.7$ & $37.7 \pm 6.3$ & $37.5 \pm 5.2$ \\
\hline Understory & $0.3 \pm 0.1$ & $0.6 \pm 0.4$ & $0.5 \pm 0.3$ \\
\hline Forest floor & $16.1 \pm 4.1$ & $40.5 \pm 3.5$ & $19.3 \pm 2.7$ \\
\hline Soil & $76.9 \pm 12.2$ & $86.5 \pm 21.7$ & $80.8 \pm 10.1$ \\
\hline$\Sigma$ Ecosystem & $125.7 \pm 16.9$ & $148.9 \pm 28.0$ & $133.6 \pm 16.2$ \\
\hline \multicolumn{4}{|l|}{ Nitrogen $\left(\mathrm{kg} \mathrm{ha}^{-1}\right)$} \\
\hline Foliage & $60 \pm 11$ & $66 \pm 10$ & $66 \pm 7$ \\
\hline Branch & $77 \pm 17$ & $74 \pm 11$ & $79 \pm 11$ \\
\hline Bole & $90 \pm 19$ & $95 \pm 17$ & $93 \pm 13$ \\
\hline Total Tree & $228 \pm 47$ & $235 \pm 37$ & $238 \pm 32$ \\
\hline Understory & $6 \pm 1$ & $6 \pm 3$ & $4 \pm 3$ \\
\hline Forest floor & $304 \pm 49$ & $519 \pm 54$ & $259 \pm 29$ \\
\hline Soil & $4445 \pm 626$ & $4564 \pm 1109$ & $3877 \pm 589$ \\
\hline$\Sigma$ Ecosystem & $4949 \pm 658$ & $5185 \pm 1155$ & $4341 \pm 576$ \\
\hline \multicolumn{4}{|c|}{ Phosphorus $\left(\mathrm{kg} \mathrm{ha}^{-1}\right)$} \\
\hline Foliage & $28.9 \pm 5.4$ & $32.1 \pm 4.9$ & $31.9 \pm 3.5$ \\
\hline Branch & $9.0 \pm 2.0$ & $8.6 \pm 1.3$ & $9.3 \pm 1.3$ \\
\hline Bole & $6.4 \pm 1.4$ & $6.7 \pm 1.2$ & $6.6 \pm 0.9$ \\
\hline Total tree & $44.3 \pm 8.7$ & $47.4 \pm 7.3$ & $47.7 \pm 5.7$ \\
\hline Understory & $0.6 \pm 0.2$ & $1.2 \pm 0.9$ & $1.1 \pm 0.7$ \\
\hline Forest Floor & $13.1 \pm 1.0$ & $28.7 \pm 5.1$ & $12.8 \pm 2.6$ \\
\hline Soil - bicarb. & $121.8 \pm 14.8$ & $57.5 \pm 10.6$ & $47.0 \pm 15.9$ \\
\hline Soil - bray & $113.5 \pm 15.3$ & $72.5 \pm 13.0$ & $49.5 \pm 13.5$ \\
\hline$\Sigma$ Ecosystem-Bi & $170.2 \pm 17.2$ & $144.4 \pm 20.4$ & $110.0 \pm 17.2$ \\
\hline$\Sigma$ Ecosystem-Br & $178.7 \pm 11.9$ & $130.1 \pm 18.3$ & $107.2 \pm 18.9$ \\
\hline \multicolumn{4}{|c|}{ Potassium $\left(\mathrm{kg} \mathrm{ha}^{-1}\right)$} \\
\hline Foliage & $79 \pm 15$ & $88 \pm 13$ & $87 \pm 10$ \\
\hline Branch & $51 \pm 11$ & $49 \pm 7$ & $53 \pm 8$ \\
\hline Bole & $54 \pm 12$ & $57 \pm 10$ & $56 \pm 8$ \\
\hline Total Tree & $185 \pm 37$ & $194 \pm 30$ & $196 \pm 25$ \\
\hline Understory & $2 \pm 1$ & $5 \pm 3$ & $4 \pm 2$ \\
\hline Forest floor & $29 \pm 4$ & $96 \pm 13$ & $48 \pm 11$ \\
\hline Soil & $1074 \pm 190$ & $1181 \pm 301$ & $992 \pm 239$ \\
\hline$\Sigma$ Ecosystem & $1279 \pm 183$ & $1436 \pm 331$ & $1248 \pm 253$ \\
\hline \multicolumn{4}{|l|}{ Calcium $\left(\mathrm{kg} \mathrm{ha}^{-1}\right)$} \\
\hline Foliage & $94 \pm 17$ & $104 \pm 16$ & $104 \pm 11$ \\
\hline Branch & $57 \pm 13$ & $54 \pm 8$ & $59 \pm 8$ \\
\hline Bole & $103 \pm 22$ & $109 \pm 19$ & $106 \pm 15$ \\
\hline Total tree & $254 \pm 52$ & $267 \pm 43$ & $268 \pm 35$ \\
\hline
\end{tabular}


Table II. Continued.

\begin{tabular}{|c|c|c|c|}
\hline & Unharvested & Cut-to-length thinning & Whole-tree thinning \\
\hline \multicolumn{4}{|c|}{ Calcium (kg ha-1) } \\
\hline Understory & $3 \pm 1$ & $6 \pm 4$ & $5 \pm 3$ \\
\hline Forest floor & $206 \pm 32$ & $392 \pm 48$ & $264 \pm 46$ \\
\hline Soil & $5938 \pm 1098$ & $3790 \pm 1012$ & $3900 \pm 833$ \\
\hline$\Sigma$ Ecosystem & $6384 \pm 1094$ & $4383 \pm 1021$ & $4360 \pm 793$ \\
\hline \multicolumn{4}{|c|}{ Magnesium $\left(\mathrm{kg} \mathrm{ha}^{-1}\right)$} \\
\hline Foliage & $46 \pm 9$ & $51 \pm 8$ & $51 \pm 6$ \\
\hline Branch & $15 \pm 3$ & $14 \pm 2$ & $15 \pm 2$ \\
\hline Bole & $20 \pm 4$ & $21 \pm 4$ & $20 \pm 3$ \\
\hline Total tree & $81 \pm 16$ & $87 \pm 14$ & $87 \pm 11$ \\
\hline Understory & $3 \pm 1$ & $3 \pm 1$ & $2 \pm 1$ \\
\hline Forest floor & $24 \pm 2$ & $53 \pm 6$ & $27 \pm 4$ \\
\hline Soil & $992 \pm 223$ & $571 \pm 221$ & $745 \pm 209$ \\
\hline$\Sigma$ Ecosystem & $1096 \pm 215$ & $698 \pm 228$ & $856 \pm 202$ \\
\hline \multicolumn{4}{|c|}{ Sulfur $\left(\mathrm{kg} \mathrm{ha}^{-1}\right)$} \\
\hline Foliage & $8.2 \pm 1.5$ & $9.0 \pm 1.4$ & $9.0 \pm 1.0$ \\
\hline Branch & $3.7 \pm 0.8$ & $3.5 \pm 0.5$ & $3.8 \pm 0.5$ \\
\hline Bole & $3.6 \pm 0.8$ & $3.8 \pm 0.7$ & $3.7 \pm 0.5$ \\
\hline Total tree & $15.4 \pm 3.1$ & $16.3 \pm 2.5$ & $16.5 \pm 2.0$ \\
\hline Understory & $0.2 \pm 0.1$ & $0.4 \pm 0.3$ & $0.3 \pm 0.2$ \\
\hline Forest floor & $14.0 \pm 1.9$ & $32.7 \pm 5.6$ & $14.3 \pm 2.1$ \\
\hline Soil & $11.0 \pm 1.4$ & $2.9 \pm 1.7$ & $3.3 \pm 0.6$ \\
\hline$\Sigma$ Ecosystem & $39.5 \pm 5.1$ & $47.1 \pm 7.3$ & $33.1 \pm 3.6$ \\
\hline
\end{tabular}

of total ecosystem $\mathrm{N}$ in the treatment plots. The only statistically significant differences in soil contents among harvest treatments were in the case of Bray- $\mathrm{P}$ and $\mathrm{SO}_{4}^{2-}$, where the CONT plots had greater contents than either the CTL or WT plots.

Estimated C and nutrient removals with the CTL and WT treatments are given in Table III and $t$-test results for the differences in removal due to harvest treatment are given in Table V. (The reader should recall that actual measurements were made after harvesting; pre-harvest values for tree $\mathrm{C}$ and nutrients were calculated from stump diameters.) The added removal of branches and foliage in the WT treatment increased $\mathrm{C}$ removal by $75 \%$ (from 14.5 to $25.3 \mathrm{Mg} \mathrm{ha}^{-1}$ ), but caused estimated removals of $\mathrm{N}, \mathrm{P}, \mathrm{K}, \mathrm{Ca}, \mathrm{Mg}$ and $\mathrm{S}$ to increase by 226, 883, 347, 223,443 and $470 \%$, respectively. In part, the differences in C and nutrient removals with harvest were due to the estimated removal of $3.6 \mathrm{Mg} \mathrm{ha}^{-1}$ more in bole $\mathrm{C}$ from the WT treatment than the CTL treatment; however, while the larger bole removal accounted for $34 \%$ of the additional $\mathrm{C}$ removed by WT, it accounted for only 3 to $11 \%$ of the additional nutrients removed. Adding branches and foliage to the harvest in the WT treatment added $39 \%$ to the C removal, but 157 to $643 \%$ to the nutrient removal because of the higher concentrations of nutrients in foliage and branches as compared to boles.
Carbon and nutrient losses due to burning are shown in Table IV and statistical analyses of the effects of harvest treatment on burning losses are shown in Table V. The values in Table IV include losses measured by changes in forest floor, large woody fuels, and understory but not soil changes. Although some changes in soil concentrations in surface horizons were found after the fire (Murphy et al., 2006), no statistically significant effects of burning were found when soil $\mathrm{C}$ and nutrients were converted to $\mathrm{a} \mathrm{kg} \mathrm{ha}^{-1}$ basis. Thus, soil changes due to burning are not included in Table IV.

Murphy et al (2006) previously estimated C and nutrient losses due to forest floor combustion; in this study, we added the component lost by understory burning and found it to be negligible in comparison to forest floor losses. All harvest treatments showed statistically significant $(P<0.05$, student's t-test) losses of $\mathrm{C}$ and $\mathrm{N}$ with burning, but only the CTL treatment showed significant losses of P, K, Ca, and S (Tab. IV). The forest floor in the CONT plots lost $51 \%$ of their C content and $43 \%$ of their N content; the CTL plots lost 62, 53, 38, 64, 35 , and $49 \%$ of their initial C, N, P, K, Ca, and S contents; and the WT plots lost 32 and $28 \%$ of their initial $\mathrm{C}$ and $\mathrm{N}$ contents, respectively. Despite the large differences in burning losses of the latter nutrients among harvest treatments, only C losses were statistically significant at the $P<0.05$ level 
Table III. Estimated carbon and nutrient removal with harvest.

\begin{tabular}{|c|c|c|}
\hline & Cut to length & Whole-tree harvest \\
\hline \multicolumn{3}{|c|}{ Carbon $\left(\mathrm{Mg} \mathrm{ha}^{-1}\right)$} \\
\hline Foliage & & $1.8 \pm 0.3$ \\
\hline Branch & & $5.3 \pm 0.7$ \\
\hline Bole & $14.5 \pm 2.8$ & $18.1 \pm 2.4$ \\
\hline Total & $14.5 \pm 2.8$ & $25.3 \pm 3.3$ \\
\hline \multicolumn{3}{|c|}{ Nitrogen $\left(\mathrm{kg} \mathrm{ha}^{-1}\right)$} \\
\hline Foliage & & $46 \pm 7$ \\
\hline Branch & & $54 \pm 7$ \\
\hline Bole & $50 \pm 10$ & $62 \pm 8$ \\
\hline Total & $50 \pm 10$ & $162 \pm 22$ \\
\hline \multicolumn{3}{|c|}{ Phosphorus $\left(\mathrm{kg} \mathrm{ha}^{-1}\right)$} \\
\hline Foliage & & $22.1 \pm 3.2$ \\
\hline Branch & & $6.3 \pm 0.8$ \\
\hline Bole & $3.5 \pm 0.7$ & $4.4 \pm 0.6$ \\
\hline Total & $3.5 \pm 0.7$ & $32.8 \pm 4.6$ \\
\hline \multicolumn{3}{|c|}{ Potassium $\left(\mathrm{kg} \mathrm{ha}^{-1}\right)$} \\
\hline Foliage & & $61 \pm 9$ \\
\hline Branch & & $35 \pm 5$ \\
\hline Bole & $30 \pm 6$ & $38 \pm 5$ \\
\hline Total & $30 \pm 6$ & $134 \pm 18$ \\
\hline \multicolumn{3}{|c|}{ Calcium $\left(\mathrm{kg} \mathrm{ha}^{-1}\right)$} \\
\hline Foliage & & $72 \pm 11$ \\
\hline Branch & & $40 \pm 5$ \\
\hline Bole & $57 \pm 11$ & $71 \pm 9$ \\
\hline Total & $57 \pm 11$ & $183 \pm 25$ \\
\hline \multicolumn{3}{|c|}{ Magnesium $\left(\mathrm{kg} \mathrm{ha}^{-1}\right)$} \\
\hline Foliage & & $35 \pm 5$ \\
\hline Branch & & $10 \pm 1$ \\
\hline Bole & $11 \pm 2$ & $14 \pm 2$ \\
\hline Total & $11 \pm 2$ & $60 \pm 8$ \\
\hline \multicolumn{3}{|c|}{ Sulfur $\left(\mathrm{kg} \mathrm{ha}^{-1}\right)$} \\
\hline Foliage & & $6 \pm 1$ \\
\hline Branch & & $3 \pm 0.3$ \\
\hline Bole & $2.0 \pm 0.4$ & $3 \pm 0.3$ \\
\hline Total & $2.0 \pm 0.4$ & $11 \pm 2$ \\
\hline
\end{tabular}

among all harvest treatments. The differences in N, K, and S losses by burning among harvest treatments was nearly significant at $P=0.054,0.091$, and 0.066, respectively. Comparing the CTL and WT treatments only (student's t-tests, $P<0.05$ ), the differences in $\mathrm{C}$ and $\mathrm{N}$ losses were significant and the differences in $\mathrm{P}, \mathrm{K}, \mathrm{Mg}$, and $\mathrm{S}$ losses were marginally significant $(P<0.10)$.

Figure 1 shows the combined nutrient losses with harvesting plus burning in the three harvest treatments and Table $\mathrm{V}$ shows the results of statistical analyses. When the CONT treat-
Table IV. Carbon and nutrient losses with burning.

\begin{tabular}{|c|c|c|c|}
\hline & Control & Cut to length & Whole tree \\
\hline \multicolumn{4}{|c|}{ Carbon $\left(\mathrm{Mg} \mathrm{ha}^{-1}\right)$} \\
\hline Detritus & $9.0 \pm 3.8$ & $25.1 \pm 5.4$ & $3.9 \pm 2.1$ \\
\hline Understory & $0.2 \pm 0.04$ & $0.2 \pm 0.05$ & $0.5 \pm 0.3$ \\
\hline Total & $9.2 \pm 3.8$ & $25.3 \pm 5.4 * *$ & $4.4 \pm 2.3$ \\
\hline \multicolumn{4}{|c|}{ Nitrogen $\left(\mathrm{kg} \mathrm{ha}^{-1}\right)$} \\
\hline Detritus & $133 \pm 65$ & $273 \pm 71$ & $38 \pm 23$ \\
\hline Understory & $5 \pm 1$ & $3 \pm 1$ & $4 \pm 3$ \\
\hline Total & $138 \pm 66$ & $276 \pm 71 * *$ & $42 \pm 24$ \\
\hline \multicolumn{4}{|c|}{ Phosphorus (kg ha ${ }^{-1}$ ) } \\
\hline Detritus & $2.9 \pm 2.2$ & $12.2 \pm 5.8$ & $1.3 \pm 1.3$ \\
\hline Understory & $0.3 \pm 0.1$ & $0.3 \pm 0.1$ & $0.3 \pm .01$ \\
\hline Total & $3.2 \pm 2.2$ & $12.5 \pm 5.8$ & $1.6 \pm 2.0$ \\
\hline \multicolumn{4}{|c|}{ Potassium $\left(\mathrm{kg} \mathrm{ha}^{-1}\right)$} \\
\hline Detritus & $9 \pm 6$ & $48 \pm 18$ & $13 \pm 6$ \\
\hline Understory & $2 \pm 1$ & $1 \pm 1$ & $4 \pm 3$ \\
\hline Total & $11 \pm 6$ & $49 \pm 18^{* *}$ & $17 \pm 9$ \\
\hline \multicolumn{4}{|c|}{ Calcium $\left(\mathrm{kg} \mathrm{ha}^{-1}\right)$} \\
\hline Detritus & $31 \pm 31$ & $138 \pm 81$ & $38 \pm 30$ \\
\hline Understory & $2 \pm 1$ & $1 \pm 1$ & $5 \pm 3$ \\
\hline Total & $33 \pm 31$ & $139 \pm 81$ & $43 \pm 29$ \\
\hline \multicolumn{4}{|c|}{ Magnesium $\left(\mathrm{kg} \mathrm{ha}^{-1}\right)$} \\
\hline Detritus & $6 \pm 4$ & $22 \pm 9$ & $3 \pm 2$ \\
\hline Understory & $2 \pm 1$ & $1 \pm 1$ & $2 \pm 1$ \\
\hline Total & $8 \pm 4$ & $23 \pm 10$ & $5 \pm 3$ \\
\hline \multicolumn{4}{|c|}{ Sulfur $\left(\mathrm{kg} \mathrm{ha}^{-1}\right)$} \\
\hline Detritus & $2.8 \pm 2.5$ & $16.4 \pm 6.5$ & $2.3 \pm 1.4$ \\
\hline Understory & $0.1 \pm 0.0$ & $0.1 \pm 0.0$ & $0.3 \pm 0.2$ \\
\hline Total & $2.9 \pm 2.4$ & $16.5 \pm 6.5^{* *}$ & $2.6 \pm 1.6$ \\
\hline
\end{tabular}

$* *$ and $* * *$ indicate significant changes pre and post-fire, student's $t$-test, $P<0.05$ and $P<0.01$, respectively.

ment was included, harvest treatment had significant effects on the combined losses of $\mathrm{C}, \mathrm{P}, \mathrm{K}$, and $\mathrm{Mg}$ and marginally significant effects on the combined losses of $\mathrm{Ca}(P=0.073)$ and $\mathrm{S}(P=0.056)($ Tab. IV). When comparing the CTL and WT treatments only (student's $t$-tests, $P<0.05$ ), the differences in combined nutrient losses were significant for $\mathrm{P}, \mathrm{K}$, and $\mathrm{Mg}$ but not $\mathrm{C}, \mathrm{N}$, or $\mathrm{S}$. The combined losses of $\mathrm{C}$ were of order $\mathrm{WT} \approx$ $\mathrm{CTL}>\mathrm{CONT}$; those of $\mathrm{P}$ and $\mathrm{K}$ were $\mathrm{WT}>\mathrm{CTL}>\mathrm{CONT}$; and those of $\mathrm{Mg}$ were $\mathrm{WT} \approx \mathrm{CTL} \approx \mathrm{CONT}$, but WT $>\mathrm{CONT}$ (Fig. 1). Burning constituted a substantially greater fraction of total $\mathrm{C}$ and nutrient removals in the CTL than in the WT treatment. Burning accounted for $67,85,75,68,71,48$, and $94 \%$ of the total removals of C, N, P, K, Ca, Mg and S from the CTL site whereas it constituted $22,38,8,16,10,<1$, and $27 \%$ of those nutrients, respectively in the WT site. 
Table V. Probability values for the effects of harvest treatment on $\mathrm{C}$ and nutrient losses by harvesting, burning, and harvesting + burning in the cut to length (CTL) and whole-tree harvest (WT) treatments (student's $t$-test) and for burning in all harvest treatments (including no harvest control). Numbers in bold indicate statistically significant results, $P<0.05$.

\begin{tabular}{|c|c|c|c|c|c|}
\hline & \multicolumn{3}{|c|}{ Comparisons of CTL and WT } & \multicolumn{2}{|c|}{$\begin{array}{l}\text { Tests of harvest effects on } \\
\text { burning in all treatments }\end{array}$} \\
\hline & Harvest & Burn & Harvest + Burn & $\mathrm{df}$ & $P$ \\
\hline Carbon & 0.060 & 0.012 & 0.136 & 2 & 0.014 \\
\hline Nitrogen & 0.026 & 0.020 & 0.271 & 2 & 0.054 \\
\hline Phosphorus & 0.021 & 0.090 & 0.024 & 2 & 0.167 \\
\hline Potassium & 0.024 & 0.081 & 0.032 & 2 & 0.091 \\
\hline Calcium & 0.027 & 0.159 & 0.330 & 2 & 0.324 \\
\hline Magnesium & 0.023 & 0.070 & 0.036 & 2 & 0.126 \\
\hline Sulfur & 0.023 & 0.060 & 0.060 & 2 & 0.066 \\
\hline
\end{tabular}

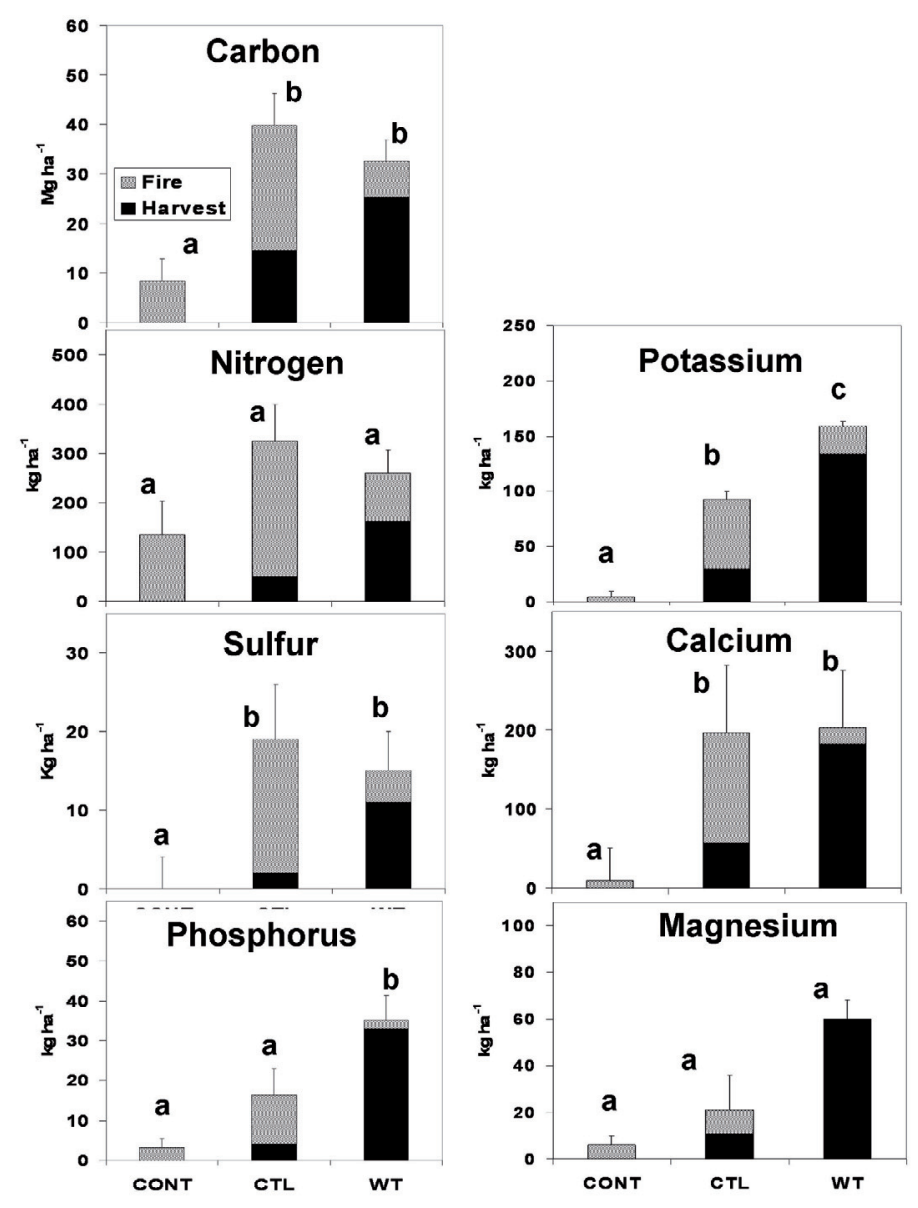

Figure 1. Combined effects of harvesting and prescribed fire on carbon and nutrient losses from the sites. CONT = control, burning but no harvesting; CTL = cut to length, thinning, with slash from foliage, branches, and tops left on site; WT = whole-tree thinning. Standard errors are shown. Harvest treatments not sharing the same letters are significantly different, $P<0.05$, LSD. 


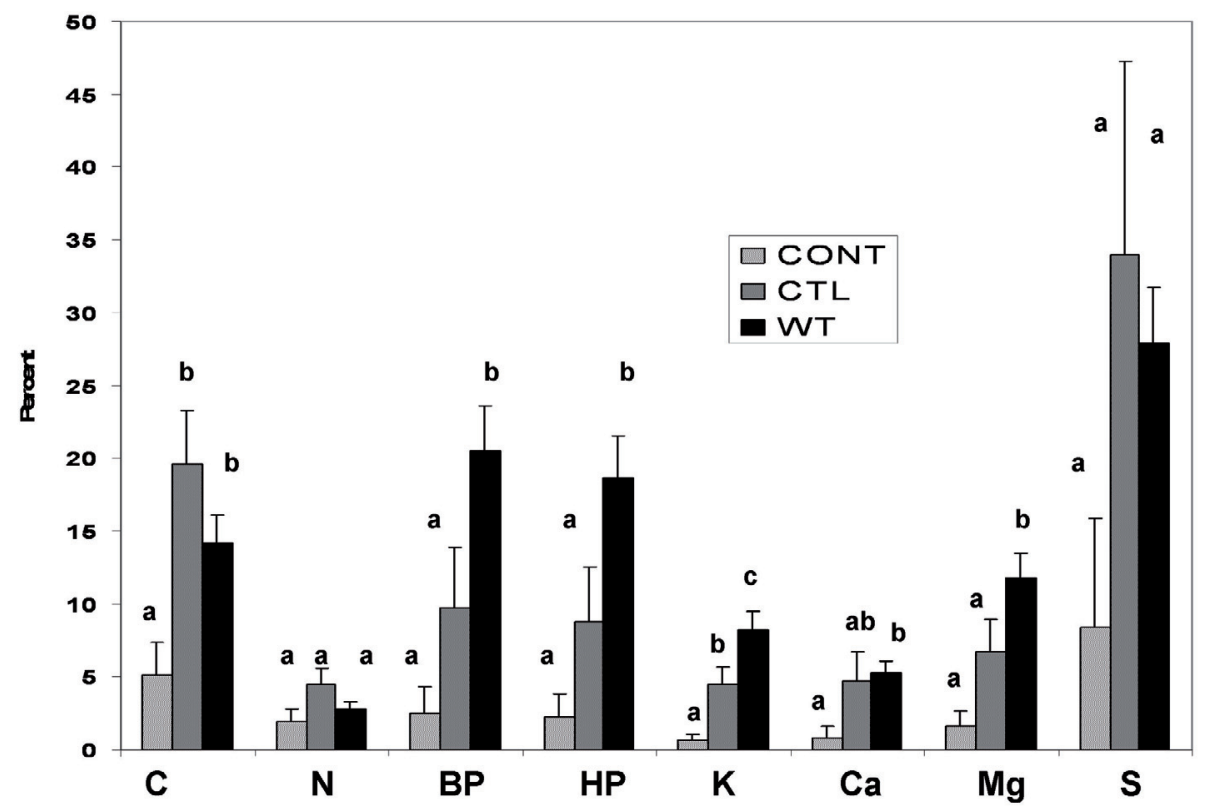

Figure 2. Carbon and nutrient removals as a percentage of nutrient capitals. Nutrient capitals for $\mathrm{C}$ and $\mathrm{N}$ include soil total pools, those for BP (Bray extractable P in soil), HP (bicarbonate-extractable P in soils), K, Ca, Mg, and S include extractable soil pools only. Standard errors are shown. Harvest treatments not sharing the same letters are significantly different, $P<0.05$, LSD.

\section{DISCUSSION}

A large body of literature has shown that whole-tree harvesting removes a disproportionate amount of nutrients compared to bole-only harvesting because it includes nutrient-rich foliar and branch tissues (Boyle et al., 1973; Johnson et al., 1982; Mann et al., 1988; Weetman and Weber, 1972). Losses due to prescribed fire, on the other hand, are usually limited to $\mathrm{N}$ and, to a lesser degree $\mathrm{S}$, which are the most volatile nutrients. In this particular study, the combined effects of harvesting and burning caused similar amounts of $\mathrm{C}$ and $\mathrm{N}$ removal in the two harvested treatments; the difference was in the mechanism of removal. In the WT treatment, most $\mathrm{C}, \mathrm{N}$ and $\mathrm{S}$ were removed via harvesting whereas in the CTL treatment, these nutrients were removed mostly by burning, which included the large stores of $\mathrm{C}, \mathrm{N}$, and $\mathrm{S}$ left in the slash rows after harvesting. For the less volatile nutrients, removal by burning was much less important than harvesting and therefore total removals of $\mathrm{P}, \mathrm{K}$, and $\mathrm{Mg}$ were greatest in the WT treatment. There was some suggestion that the more intense burning in the slash rows of the CTL treatment caused greater losses of the less volatile nutrients: $\mathrm{K}, \mathrm{Ca}$, and $\mathrm{Mg}$ losses by burning were statistically significant in the CTL but not in the WT or CONT treatments. This effect did not outweigh the importance of harvesting for these nutrients, however, and thus total removals of $\mathrm{P}, \mathrm{K}$, and $\mathrm{Mg}$ were greatest in the WT treatment.

In order to assess the significance of these nutrient exports, they need to be put into perspective with respect to (1) total nutrient capital on these sites and (2) potential replenishment by atmospheric deposition and nitrogen fixation. Figure 2 depicts the nutrient exports by harvesting + burning as a percentage of ecosystem capital. In this figure, the $\mathrm{C}$ and nutrient capital before the harvest is used as the basis. Pre-harvest tree $\mathrm{C}$ and nutrient content was assumed to equal post-harvest tree contents plus harvest removals; pre-harvest forest floor $\mathrm{C}$ and nutrient content was assumed to equal forest floor content measured in the non-slash pile/skid row areas of the plots (since no preharvest forest floor samples were taken).

The percentage of ecosystem $\mathrm{C}$ removal by harvesting plus burning was greater in the harvested treatments (20-29\%) than in the CONT treatment (5\%), but the differences between harvest treatments were not significant (Fig. 2). Although the percent ecosystem $\mathrm{N}$ capital removed by harvesting plus burning was approximately twice as great for the harvested treatments (4\% in each) than in the unharvested treatment $(2 \%)$, the effects of harvest treatment were not statistically significant. For P, the percent removal of ecosystem capital (defined using only extractable $\mathrm{P}$, both for Bray and bicarbonate) was significantly greater $(P<0.05)$ in the WT $(20-22 \%)$ than in the CTL $(9-10 \%)$ or CONT (2-3\%) treatments, the latter of which were not significantly different from one another. For K (including exchangeable soil contents only), differences in all harvesting treatments were significant, with WT $(8 \%)>$ CTL $(5 \%)>$ CONT $(<1 \%)$. For Ca (including exchangeable soil contents only), percent removal by WT (6\%) was greater than in CONT $(<1 \%)$ and removal by CTL $(5 \%)$ was not significantly different from either WT or CONT. For Mg, removal by WT $(12 \%)$ was greater than both CTL (7\%) and CONT (2\%), 
Table VI. Number of years to replace nutrients lost by harvesting and burning by atmospheric deposition. The three scenarios are wet only deposition, and assumptions that dry deposition adds $100 \%$ and $200 \%$ to wet inputs. (Data on N, K, Ca, Mg and S from the NADP station at Sagehen, California; P data is from Johnson et al 1997 for a snowmelt inputs to the NADP site at Sagehen prior to the installation of the NADP samples.)

\begin{tabular}{|c|c|c|c|c|c|c|}
\hline & $\mathrm{N}$ & $\mathrm{P}$ & $\mathrm{K}$ & $\mathrm{Ca}$ & $\mathrm{Mg}$ & $\mathrm{S}$ \\
\hline & \multicolumn{6}{|c|}{ (years) } \\
\hline \multicolumn{7}{|l|}{ Wet } \\
\hline Cut-to-length thinning & 663 & 66 & 1588 & 1157 & 1157 & 80 \\
\hline Whole-tree thinning & 414 & 140 & 3020 & 1318 & 2123 & 59 \\
\hline Cut-to-length thinning & 332 & 33 & 794 & 579 & 578 & 40 \\
\hline Whole-tree thinning & 207 & 70 & 1510 & 659 & 1067 & 30 \\
\hline \multicolumn{7}{|c|}{$200 \%$ increase with dry deposition } \\
\hline No harvest & 94 & 4 & 67 & 61 & 81 & 4 \\
\hline
\end{tabular}

the latter of which were not significantly different. Finally, for $\mathrm{S}$ removal, there were no significant differences among harvest treatments even though removals in WT $(36 \%)$ and CTL (34\%) were considerably greater than in the CONT $(8 \%)$ treatment.

The removals of $\mathrm{C}$ in the harvested treatments constitute a substantial proportion (16-20\%) of ecosystem C capital and thus may be of concern relative to the effects of these treatments on $\mathrm{C}$ sequestration on site. However, these values must be placed into context as to (a) what if any proportion of the $\mathrm{C}$ removed is sequestered in long-lived buildings, and (b) the likelihood of insect attacks and/or a stand-replacing wildfire induced by the lack of thinning and fuel reduction. A standreplacing wildfire would likely remove all of the forest floor and a variable proportion of aboveground at the onset. Assuming that the trees were killed in such a fire (as would be the case by definition of a stand-replacing wildfire), the woody biomass not burned would either be removed by salvage logging or left to decay in the field. Thus, a stand-replacing wildfire in the unburned CONT treatment, for example, would cause the removal of over $40 \%$ of ecosystem $\mathrm{C}$ capital, given these assumptions.

On face value, the nutrients that appear to present the most potential problems (those whose removal as a percent of ecosystem capital are greatest) are P and S. For both P and $\mathrm{S}$, however, the ecosystem capital is defined somewhat arbitrarily as including only extractable soil quantities. Susfalk (2000) conducted extensive research on P fractions in similar soils near this site and found that the capacity of these andic soils to supply $\mathrm{P}$ greatly exceeds the amounts immediately extractable by either Bray or bicarbonate. In the case of $\mathrm{S}$, the values shown here reflect only water-extractable soil amounts and are therefore likely to greatly underestimate $\mathrm{S}$ supply capacity as well. The removals of $\mathrm{N}$, the most limiting nutrient, constitute only small fractions $(<5 \%)$ of ecosystem capital even in the harvested treatments where $\mathrm{N}$ removal rates were greatest.

Table VI presents a calculation of the number of years of atmospheric deposition that would be required to replenish nutrients removed via harvesting and burning in the various treatments. The data used for this analysis come from the nearby National Atmospheric Deposition Program (NADP) site at Sagehen Experimental Watershed, which is $<5 \mathrm{~km}$ from the site and at approximately the same elevation. The NADP data include wet deposition only; thus, two additional scenarios are shown, one in which dry deposition doubles and triples total wet deposition (Tarnay et al., 2002). The nutrients for which removals would take the longest time to replenish given current atmospheric deposition rates (and the associated assumptions about dry deposition) are $\mathrm{K}>\mathrm{Mg}>\mathrm{Ca}>\mathrm{N}>\mathrm{P}>\mathrm{S}$. Thus, in contrast to the analysis based on percent of ecosystem capital removed, it appears that $\mathrm{P}$ and (especially) $\mathrm{S}$ removals pose the least potential nutrient problems with harvesting and burning when considered in the context of potential replenishment by atmospheric deposition. The years to replenish $\mathrm{K}$, $\mathrm{Ca}$, and $\mathrm{Mg}$ removals are substantial, but the percentage removals of these nutrients from the site by harvesting and burning are quite small $(<5 \%$ in most cases) and would be even smaller had we analyzed total rather than extractable amounts of these nutrients and had we been able to sample soils at greater depths. Thus, it would not appear that removals of $\mathrm{K}$, $\mathrm{Ca}$, or $\mathrm{Mg}$ pose significant potential nutrient problems, either.

Current levels of atmospheric $\mathrm{N}$ deposition at this relatively unpolluted site would not come close to replenishing $\mathrm{N}$ lost even by burning alone, let alone harvesting. Although $\mathrm{N}$ removals constitute only a small fraction of total ecosystem capital $(<5 \%)$, it must be noted that only a small proportion of total soil $\mathrm{N}$ (which constitutes $50-60 \%$ of ecosystem capital) is available to plants. Thus, $\mathrm{N}$ is the nutrient whose removal by harvesting and burning has the greatest likelihood of 
posing a potential limitation in the future under this management regime. The values in Table VI do not, however, include potential inputs of $\mathrm{N}$ by fixation or exports by leaching. Two species in the understory at the time, squaw carpet and bitterbrush, fix nitrogen and could be making a substantial contribution to $\mathrm{N}$ inputs. Studies are now in progress to estimate $\mathrm{N}$ fixation rates by these two species. Measuring leaching losses from below the rooting zone is very problematic in these systems where taproots may extend well beyond $2 \mathrm{~m}$ depths. We can, however, refer to the fact that Murphy et al. (2006) found no effects of any treatment on $\mathrm{N}$ or $\mathrm{P}$ leaching at $15 \mathrm{~cm}$, and thus it seems unlikely that treatments affected leaching below the rooting zone either. Nitrogen and leaching rates measured at $30 \mathrm{~cm}$ depth in a similar, nearby forest stand were estimated at $0.6 \mathrm{~kg} \mathrm{ha}^{-1} \mathrm{y}^{-1}$. Nitrogen removals by harvesting and burning in the CONT, CTL, and WT sites would equal 230, 543, and 340 years of $\mathrm{N}$ leaching at $0.6 \mathrm{~kg} \mathrm{ha}^{-1} \mathrm{y}^{-1}$, respectively. However, the $\mathrm{N}$ leaching rate below the rooting zone is probably much lower than that measured at $30 \mathrm{~cm}$ and thus the number of years of leaching calculated to equal $\mathrm{N}$ removal by harvesting and burning are probably much underestimated. Thus, it seems safe to say that $\mathrm{N}$ removals at these sites are dominated by removal in harvested biomass and burning with only secondary contributions by leaching, and furthermore, harvesting and burning treatment effects on $\mathrm{N}$ leaching were not significant.

\section{SUMMARY AND CONCLUSIONS}

Hypothesis H1 (Carbon and nutrient removals by combined harvesting and burning will be greater in the harvest treatments (CTL and WT) than in the unharvested (CONT) treatment) was supported only in part by the results of this study. Whereas the total removals of $\mathrm{C}, \mathrm{P}, \mathrm{K}$, and $\mathrm{Mg}$ were significantly greater in one or more harvest treatments as compared to control, differences in $\mathrm{N}, \mathrm{S}$, and $\mathrm{Ca}$ were not significant. However, in each case the absolute values of the removals by harvesting and burning were greater than those of harvesting alone.

Hypothesis H2 (Harvest treatment will have little effect on the combined effects of harvesting and burning on $\mathrm{C}$ and $\mathrm{N}$ losses despite the large differences in removal by harvesting because $\mathrm{C}$ and $\mathrm{N}$ in residues left in CTL treatments will be substantially lost during burning) was supported in large measure by the results of this study. There were no significant differences in the combined effects of harvesting and burning on the total removals of $\mathrm{C}$ or $\mathrm{N}$ between the CTL and WT treatments.

Hypothesis H3 (Harvesting will be the dominant mechanism for $\mathrm{C}$ and $\mathrm{N}$ removal in the WT treatment whereas burning will dominate $\mathrm{C}$ and $\mathrm{N}$ removal in the CTL treatment) was supported by the results of this study. Burning accounted for 67 and $85 \%$ of $\mathrm{C}$ and $\mathrm{N}$ loss, respectively, in the CTL treatment and only 22 and $38 \%$ (respectively) in the WT treatment. Statistically significant net losses of $\mathrm{P}, \mathrm{K}, \mathrm{Ca}$, and $\mathrm{S}$ also occurred with burning in the CTL treatment whereas losses of these nutrients by burning in the WT treatment were much smaller and not statistically significant.
Hypothesis H4 (Harvesting treatments will dominate losses of $\mathrm{P}, \mathrm{K}, \mathrm{Ca}$, and $\mathrm{Mg}$, and removals will be greatest in WT) was supported in most cases. As noted above, burning accounted for significant losses of P, K, and Ca in the CTL treatment, and in this treatment, burning constituted the greatest proportion of total losses by harvesting and burning combined. Total removals of $\mathrm{P}$ and $\mathrm{K}$ were total removals greater in the WT than in the CTL treatment.

Comparisons of nutrient removals with ecosystem capital (the latter including only extractable contents for $\mathrm{P}, \mathrm{K}, \mathrm{Ca}, \mathrm{Mg}$ and $\mathrm{S}$ ) and calculations of potential replenishment of nutrient losses by atmospheric deposition collectively suggest that $\mathrm{N}$ is the nutrient likely to be most depleted by harvesting and burning treatments. However, this does not include potential inputs by $\mathrm{N}$ fixers at the site, an issue what will be addressed in a future paper.

Acknowledgements: This research was supported by the U.S. Forest Service and the Nevada Agricultural Experiment Station, University of Nevada, Reno, Nevada USA. We greatly appreciate technical assistance by Valerie Yturiaga, Donn Geisinger, Matt Donaldson, Andrew Diedrichsen, and Damien Domini. This is publication Nevada Agricultural Experiment Station.

\section{REFERENCES}

Avery T.E. and Burkhart H.E., 2002. Forest measurements. 5th ed., McGraw-Hill, New York, 456 p.

Blank R.R. and Zamudio D.C., 1998. The influence of wildfire on aqueous-extractable soil solutes in forested and wet meadow ecosystems along the eastern front of the Sierra-Nevada range, California. Int. J. Wildland Fire 8: 79-85.

Boyle J.R., Phillips J.J., and Ek A.R., 1973 "Whole Tree" Harvesting: Nutrient Budget Evaluation. J. For. 71: 760-762

Caldwell T.G., Johnson D.W., Miller W.W., and Qualls R.G., 2002. Forest Floor Carbon and Nitrogen Losses Due to Prescription Fire. Soil Sci. Soc. Am. J. 66: 262-267.

Carmer S.G. and Swanson M.R., 1973. An evaluation of ten pairwise multiple comparison procedures by Monte Carlo methods. J. Am. Stat. Assoc. 68: 66-74.

Certini G., 2005. Effects of fire on properties of forest soils: a review. Oecologia 143: 1-10.

Fecko R.M., Walker R.F., Frederick W.B., Miller W.W., and Johnson D.W., 2008a. Stem dimensional fluctuation in Jeffrey pine from variation in water storage as influenced by thinning and prescribed fire. Ann For. Sci. 65:201.

Fecko R.M., Walker R.F., Frederick W.B., Miller W.W., and Johnson D.W., 2008b. The effects of mechanical thinning and prescribed fire on stand structure, live crown, and mortality in Jeffery pine. J. Sustain. For. (in press).

Gholz H., Grier C.C., Campbell A., and Brown A., 1979. Equations for estimating biomass and leaf area of plants in the Pacific Northwest. Research Paper 41. Forest Research Laboratory, Oregon State University, Corvallis, OR.

Hamburg S.P., 1984. Effects of forest growth on soil nitrogen and organic matter pools following release from subsistence agriculture. Forest Soils and Treatment Impacts Proceedings of the North American Forest Soils Conference. Knoxville, Tennessee, USA, 1984, pp. 145148.

Hosking J.S., 1938. The ignition of low temperatures of organic matter in soils. J. Agric. Sci. 38: 393-400. 
Johnson D.W. and Todd D.E., 1998. The effects of harvesting on longterm changes in nutrient pools in a mixed oak forest. Soil Sci. Soc. Am. J. 62: 1725-1735.

Johnson D.W., West D.C., Todd D.E., and Mann L.K., 1982. Effects of sawlog vs. whole-tree harvesting on the nitrogen, phosphorus, potassium, and calcium budgets of an upland mixed oak forest. Soil Sci. Soc. Am. J. 46: 1304-1309.

Johnson D.W., Kelly J.M., Swank W.T., Cole D.W., Van Miegroet H., Hornbeck J.W. Pierce R.S., and Van Lear D.H., 1988. The effects of leaching and whole-tree harvesting on cation budgets of several forests. J. Environ. Qual. 17: 418-424.

Johnson D.W., Susfalk R.B., and Dalgren R.A., 1997. Nutrient fluxes in forests of the eastern Sierra Nevada Mountains, USA. Glob. Biogeochem. Cycles 11: 673-681.

Johnson D.W., Murphy J.D., Susfalk R.B., Caldwell T.G., Miller W.W., Walker R.F., and Powers R.F., 2005. The effects of wildfire, salvage logging, and post-fire $\mathrm{N}$ fixation on the nutrient budgets of a Sierran forest. For Ecol. Manage. 220: 155-165.

Knight H., 1966. Loss of nitrogen from the forest floor by burning. Forestry Chron. 42: 241-248.

Malmer A., 1996. Hydrologic effects and nutrient losses of forest plantation establishment on tropical rainforest land in Sabah, Malaysia. J. Hydrol. 174: 129-148.

Mann L.K., Johnson D.W., West D.C., Cole D.W., Hornbeck J.W., Martin C.W., Riekerk H., Smith C.T., Swank W.T., Tritton L.M., and Van Lear D.H., 1988. Effects of whole-tree and stem-only clear- cutting on postharvest hydrologic losses, nutrient capital, and regrowth. For. Sci. 42: 412-428.
Murphy J.D., Johnson D.W., Miller W.W., Walker R.F., and Blank R.R., 2006. Prescribed fire effects on forest floor and soil nutrients in a Sierra Nevada ecosystem. Soil Sci. 171: 181-199.

Neary D.G., Klopatek J.M., DeBano L.F., and Folliot P.F., 1999. Fire effects on belowground sustainability: a review and synthesis. For. Ecol. Manage. 122: 51-71.

Pyne S.J., 1984. Introduction to wildland fire: Fire management in the Unite States. John Wiley \& Sons, New York.

Raison R.J., Khanna P.K., and Woods P.V., 1985. Mechanisms of element transfer to the atmosphere during vegetation fires. Can. J. For. Res. 15: $132-140$.

Susfalk R.B., 2000. Relationships of soil-extractable and plant-available phosphorus in forest soils of the eastern Sierra Nevada. Graduate Program Hydrologic Sciences, Univ. Nevada, Reno, Nevada USA, $227 \mathrm{p}$.

Tarnay L., Gertler A.W., and Taylor G.E., 2002. The use of inferential models for estimating nitric acid vapor deposition to semi-arid coniferous forests. Atmos. Environ. 36: 3277-3287.

Tiedemann A.R., 1987. Combustion of losses of sulfur from forest foliage and litter. For. Sci. 33: 216-223.

Walker R.F., Fecko R.M., Frederick W.B., Murphy J.D., and Johnson D.W., 2006. Thinning and prescribed fire effects on forest floor fuels in the east side Sierra Nevada pine type. J. Sustain. For. 23: 99-114.

Weetman G.F. and Webber B., 1972. The influence of wood harvesting on the nutrient status of two spruce stands. Can. J. For. Res. 2: 351-369.

Westerling A.L., Hidalgo H.G., Cayan D.R., and Swetnam T.W., 2006. Warming and earlier spring increases western US forest wildfire activity. Science 313: 940-943. 